\title{
Financial Statement Lending, Credit Information Sharing and Access to Financial Services by Small and Medium Enterprises in Kenya
}

\author{
Edward Simiyu Kiring'a $^{1^{*}} \quad$ Dr. Fredrick W. S. Ndede ${ }^{1} \quad$ Dr. Argan O. Wekesa ${ }^{2}$ \\ 1.School of Business, Department of Accounting and Finance, Kenyatta University, P.O BOX 43844-00100, \\ Nairobi, Kenya \\ 2.School of Computing and Mathematics, Department of Mathematical Sciences, The Cooperative University of \\ Kenya P.O. BOX 24814-00502, Karen-Nairobi, Kenya
}

\begin{abstract}
Policy makers and scholars acknowledge the significance of small and medium enterprises in stirring the economic growth and development in developing and developed economies. In spite of the generally fast pace by which access to financial services for small and medium enterprises is being established, significant segments of the small and medium enterprises sector do not yet benefit from the expansion. This study therefore investigated the effect of financial statement lending on access to financial services by small and medium enterprises in Kenya. The study further sought to establish the moderating effect of the credit information sharing on the relationship between financial statement lending and access to financial services by small and medium enterprises in Kenya. The study was based on Financial Intermediation Theory and information asymmetry theory. The target population comprised 4,253 small and medium enterprises in Kenya. A sample size of 366 SMEs was target by the study. The study adopted multistage sampling technique to obtain the SMEs respondents. Primary data was utilized and was acquired through semi-structured questionnaires. Data was analysed using descriptive and inferential statistics. Heckman two step selection model was applied in regression analysis. The findings of regression analysis show that financial statement lending had a positive and significant effect on access to financial services among SMEs in Kenya. The results established that credit information sharing had insignificant moderating effect on the relationship between financial statement lending and access to financial services among the SMEs in Kenya. The study concluded that financial statements play a critical role in ensuring small and medium enterprises access financial services. Lenders can determine the financial position of the business by analysing their cashflow in order to be able to advance the credit that the business is able to pay based on their financial statement.
\end{abstract}

Keywords: Financial Statement Lending, Financial Services, SMEs, Kenya.

DOI: $10.7176 /$ RJFA/12-16-06

Publication date:August $31^{\text {st }} 2021$

\section{Introduction}

Financial institutions emphasize on several requirements that SMEs cannot fulfill when making credit decisions. The goal of financial institutions is to maximize the profit as a result they will minimize credit risk and increase returns on credit facilities by trading with borrowers who can pay high cost of credit and have low credit risk (Boushnak, Rageb, Ragab \& Sakr, 2018). Financiers always utilise certain criteria when assessing loan requests before a warding credit. Angilella and Mazzu (2017) confirmed that banks are key in granting credit to small and medium enterprises when addressing SMEs constraints to funding. However, strict rules and regulations are observed before the loans are granted hence weakening access to funding by SMEs. When financial institutions requirements are not met by the borrower's requests, funding gap emerges leading to adverse loaning decision as well as limiting SMEs credit accessibility (Boushnak et al., 2018). SMEs evaluation and assessment principles are categorized into relationship lending, asset-based lending, financial statement lending and credit scoring lending (Kusi, Agbloyor, Ansah-Adu \& Dako, 2017). Financiers have invented certain financing practices such as relationship lending, asset-based rule, financial statement rule and credit scoring due to exceptional environment of SMEs that has led to constraints in their viability assessment (Ohachosim, Onwuchekwa \& Ifeanyi, 2017).

Financial statement lending comprises guaranteeing credits centred on strength of a borrower's financial statements. Nemoto, Yoshino, Okubo, Inaba and Yanagisawa (2018) acknowledged that financial institutions need to assess credit risk and solvency of SMEs before extending credit as a result financial statements are always essential. The decision to give a loan and the conditions of the credit agreement are predominantly based on the strength of the balance sheet, income and cash flow statements. Financiers examine financial statements to measure a business's current performamce and ability of a firm to influence settlement of loan, overall credit risk and forecast future performance (Mashkour, 2020). SMEs with lengthy histories, comparatively transparent and robust audited financial statements are eligible for financial statement lending. SME with audited financial statements have 
high chance to acquire loans at a lesser cost than those lacking.

Mbatha and Ngibe (2017) affirms that maintaining financial records is critical for every enterprise but SMEs fail owing to insufficient, erroneous or missing books. Absence of organisational accounting expertise for decision making and non-existence of practical skills to make financial statements remain considerable problem to evolving of SMEs as is the failure to access loans (Karanja, Mwangi \& Nyakarima., 2014). In respect to accountng standards, SMEs have a tendency to have inadequate financial records and involve limited or no experts unlike large firms Ezeagba, (2017) as a result SMEs finds it expensive and beyond their capability and expertise to conform to accounting standards. Deficiency of reliable information revealed in income statement, cashflow statements and statement of financial position is the prime SMEs obvious trouble to loaning.

Credit Information Sharing CIS) regulation by credit reference bureaus (CRBs) is a moderating measure aimed at helping financiers understand the repayment history of the borrower and reward the good borrowers (Otieno, Nyagol \& Onditi, 2016). Credit information sharing benefits both lenders and borrowers hence increases economic activity of a country. Credit information sharing enables financiers to have knowledge of borrowers' history of repayment, outstanding loan size and credit worthiness (WB, 2018). Credit bureaus have enabled borrowers' information availability which assists financiers to come up with appropriate cost of credit due to proper risk evaluation and thus enables ease access to financial services by borrowers (Chavez, 2017). KBA (2012) explained that information sharing through credit reference bureaus has increased access to financial services while lessening the cost of credit as borrowers are sanctioned and rewarded using past payment behaviour.

Credit information sharing can reduce information asymmetry arising from moral hazard and adverse selection (WB, 2018). SMEs owners who require credit can be denied because of adverse selection even when collateral is present and have ability to acquire credit at a higher cost. SMEs opaqueness, agency problem, information asymmetry with increased cost of credit deters SMEs owners from acquiring loans. SMEs are incapacitated with knowledge in order to produce quality financial statements, have information opacity and limited asset to collateralise (Sari, Rahmatika, Fajri \& Muttaqin, 2020). Martinez, Maria and Singh (2014) opined that improving credit information sharing policies through CRB can lead to increase in SMEs funding by 7 to $8 \%$ and a decline in interest rate by $5 \%$. Credit information sharing has been well-thought-out to be encouraging integrity and decreasing the information value that financiers have overs their borrowers, as a result low cost of borrowing emerges and improved access to loans (Brown, Ongena, Popov \& Yesin, 2011).

Small and Medium Enterprises comprise $98 \%$ of firms in the country, creating $30 \%$ of employment and $3 \%$ of gross domestic product yearly (Central Bank of Kenya, 2017). SMEs are viewed as risky and attract less the banking sector's credit (Financial Sector Deepening-Kenya, 2017). SMEs in the country are plagued with funding problems exposing them to credit risks that hinder their expansion to enjoy the benefits accrued to large scale operations. When SMEs find themselves poorly serviced by the financial institutions, their growth and development can be restricted leading to deterioration of the national economy. The financing sector contribution to economic development and growth has been weakened by non-performing loans prompting financiers to recede from providing loans to some borrowers (Ndede, Wawire \& Mbewa, 2015).

According to KNBS (2016) banks finance 5.6 per cent of SMEs, despite at least four out of every five small $(87.9 \%)$ and medium (80.6\%) enterprises owning a bank account. Small and medium enterprises as a result encounters difficulties while acquiring the credit to fund their activities. According to survey conducted by Kenya Bankers Association between April 2017 and June 2017 indicated that out of the 3.2 million SMEs who applied for a loan from banks between the month of May 2017 and June 2017 only 1.1 million had their loans approved (KBA, 2017). This means that over 2 million applications were rejected representing 34\% success rate. Further the survey revealed that loan application and disbursement over the same period dropped from 2.2 million to below 750,000 representing 32\% decline. SMEs loan approval by banks is very minimal, as a result more SMEs have failed to secure funding from this financial institutions (KNBS, 2016). Twenty five percent of adults in Kenya have no access to credit as established by CBK (2017).

From the foregoing background, it's evident that SMEs are constrained in accessing financial services. SME lending in 2015 by banks accounted for $23.4 \%$. However, a survey conducted by KBA in 2016 revealed that bank loans to SMEs had declined to $17 \%$ (CBK, 2018). Foreign banks' lending to SMEs has been reducing over time, falling from $40 \%$ in 2009 to $27 \%$ in the 2013 periods (Berg, Fuchs, Ramrattan, Totolo \& CBK, 2015). This was emphasized by a survey conducted by KBA in 2017 which showed that for any loan application done by SMEs, the success rate was 34\%. According to KNBS (2016) banks finance 5.6 per cent of SMEs, despite at least four out of every five small $(87.9 \%)$ and medium $(80.6 \%)$ enterprises owning a bank account with the banks. Similarly, CBK (2017), reported that $38.4 \%$ of SMEs are credit constrained. Failure by SMEs to secure credit from banks is estimated to have lowered growth in 2017 by $0.4 \%$ (CBK, 2018).

Inability to access credit as an obstacle experienced by SMEs is documented by various researchers including Kaberia \& Muathe (2021); Jin and Zhang (2019); OECD (2018); Chowdhury and Alam (2017); World Bank (2017); Hoque, Sultana, \& Thalil (2016) as well as Kiplimo, Ngenoh and Bett (2015). The previous studies 
conducted provided mixed conclusions on direct relationship between financial statements lending on access to financial services. The inconsistencies in this studies provided a platform of research to ascertain the reliable conclusions. Furthermore the reviewed studies measured the direct relationship between the variables, which necessitated further study on how a moderating variable can be applied to determine the combined interactions of financial statement lending with SMEs access to financial facilities. This study provides measures of mitigating SMEs problems in effort to boost access to debt. The study sought to add value to the knowledge by giving empirical proof on correlation among financing practices with SMEs access to financial services.

\section{LITERATURE REVIEW}

\subsection{Theoretical Review}

In the year 1970, Akerlof introduced the Information Asymmetry Theory. This theory argues that when two people come together and intend to make a decision on a specific issue, then one of the parties has to have more information involving the other. In this case, the client who intends to apply for a loan, normally has information involving the loan and possible interest while the loan giver has more information on the borrower which makes the lender make the decision on whether to give the borrower the loan or not and at what interest rate. The SMEs predicaments originate from fragile financial structure and absence of business information thus mystifying loan access from banks (Mazeri \& Saadouni, 2019). The borrowers are probable to have more information on investments and their information related to risk. The two then tend to have imbalance of power due to information asymmetry. This causes the financiers to slow the process of transferring funds to the SMEs. This then leads to the conclusion concerning information asymmetry as the main challenge that leads to delay of funds between financiers and SMEs. Banks and microfinance institutions cannot regulate the behaviour of borrowers as a result of imperfect and expensive information, hence they create covenants in loan agreements that reduces credit risks (Nega \& Hussein, 2016).

Financial intermediation theory established by Gurley and Shaw (1967) is grounded in this study. In economy, financially needy problems are solved by financially able agent through financial intermediation platform. The concept clarifies the impact of loans from the bank in economic development. Availing finances to SMEs by banking organization can stimulate SMEs growth. Financial institutions serve as a mediators by offering loans from saving entity to borrowing entity for investment (Andabai \& Eze, 2018). Information asymmetry costs pertaining to transaction and information amongst financiers and borrowers is narrowed in the presence of financial intermediaries. Mungiria and Ondabu (2019) postulates that productive investment can be achieved when funding is availed to firms through bank credit financial intermediation.

Bank credit is a loan to a borrower centred on profitability and risk regarding financier's analysis (Chitom \& Muogbo, 2018). Financing intermediation boost effective resource apportionment by reducing the cost of financing between financiers and borrowers. Absence of financial intermediaries leads to informational asymmetry that causes imperfections of the financial market creating occurrence of transactional costs. Employment opportunities expansion in a country originates from accessibility of financial services for investment by SMEs. Therefore, financial institutions should loan any profitable project at any time the expected return exceeds the investment cost. Financial institution intermediation role of credit offerings to SMEs is the main goal in expanding credit services to needy customers according to financial intermediation theory.

\subsection{Empirical Review}

Financial statements plays a major role when financial institutions are appraising SMEs before granting credit services. Aladejebi and Oladimeji (2019) affirmed that absence of correct financial statements reduces SMEs chances of securing bank loans. Financial institutions finds enterprises financial statements valuable during loan requests but small and medium enterprises problems of access to financial services originate from insufficiency skills to adhere to international financial reporting standards (IFRS) in preparing financial statements (UN, 2017). Financial statements are utilised by banks in monitoring SMEs and fifty percent of loans granted are based on financial statements (Minnis \& Sutherland (2016). Incapacity to provide audited fianancial statements by SMEs makes financiers unwilling to grant them loans. Kwaning, Nyantakyi and Kyereh (2015) confirmed that credit expansion by financiers to borrowers will depend on audited financial statements because presentation of this statements increases reliability of debtor's hence lenders credit risk declines.

Boushnak et al. (2018) carried out a study on reasons that influences lending to SMEs by Egypt's National Bank. The result of the study indicated that credible financial statement positively and significantly influences securing of loan from banks. In a study conducted by Ohachosim et al. (2017) on what way financial impediments can be solved by Nigeria SMEs using information of accounting. The study results indicated that quality of financial statements positively influences credit access by SMEs. Further Fuseini, Nuakoh and Amponsah (2016) did a study on credit access by SMEs in Ghana. The study findings shown that financial statements presence had a positive and significant influence on access to credit.

In a study carried out by Ezeagba (2017) in determining the effect of reporting on financial accounts in 
Nigeria and access to SMEs loans. Data was obtained through method of survey that was longitudinal in nature using questionnaires. The results discovered that inadequate human resource, poor accounting system, failure to use banking system and absence of financial statements limits funding of SMEs. In the same vain a study carried out by World Bank (2017) on impact of financial information on bank loaning practices to Serbia SMEs utilised a survey design. The study found out that financial information are heavily relied on in granting loans to SMEs. The result further revealed that low access to financing and increased credit costs results from unreliable financial statements and unsatisfactory disclosures of profits and credit risks. Amoaka (2013) supports the results by affirming that improper financial records jeopardizes SMEs chances of securing bank loan.

Conversely Pandula (2013) did an examination of SMEs in Sri Lanka on accessibility to bank loan. The results revealed that securing loan facility is positively and significantly influenced by accessibility of appraised financial statements. Aga and Reilly (2011) concurred with this findings upholding that accessibility to loans increased by six percent for firms that keep financial statements in comparison with those lacking. A study conducted by Minnis (2010) examined the influence of financial statements and pricing of private firms debt in U.S.A. The results shown that fianancial statements that are audited supply more information, significantly influencing decision by the lender to grant loans. Financiers prefer firms with audited fianancial statements in comparison to firms with unaudited financial statements hence extending lower rate of interest to audited firms as per the study findings. However, Iswoyo, Ermawati and Nugroho (2019) in a study on bank loan access and quality of SME financial statements. The study results showed that financial statements quality does not influence access to loans from banks since small and medium enterprises produces unreliable statements that are not verified hence do not reflect a true picture of the firm.

Credit information sharing is a main contributing factor that influence access to financial services by SMEs. Fosu, Danso, Agyei-Boapeah, Ntim, and Adegbite (2019) verified that CIS signifies a proper way of improving information accessible by banks enabling then in granting loans to borrowers with ease. Financing decision to award credit by banks is based on quality and quantity of information emanating from CIS bureaus. Credit information sharing offers a chance to increase loan access through information capital building (James, Iraki \& Korir, 2017). CIS alleviates information asymmetry allowing suppliers of funds to understand those in need of funds before extending credit to clients who possess robust credit history. CIS leads to expanding of quality of loaning portfolio allowing even riskier customers to access credit (Guérineau \& Léon, 2016).

In a study carried out by Balakrishnan and Ertan (2021) on Credit information sharing and recognition of loss on loan showed that CIS improves recognition of bank loss on timely basis due to revelation of NPLs. In another study conducted by Son, Khanh and Liem (2020) on financial development, corruption and credit information sharing between 2004 and 2017 in 120 republics. The study results showed that credit information sharing had significantly positively influences on financial intermediation activities. CIS led to falling of nonperforming loans and increase to loan access because of CIS influence on reducing corruption information asymmetry. In a study by Ahmad, Nazir and Nafees (2018) on trade credit influence by CIS and financial development by listed manufacturing firms in Pakistan. Time frame of the study was 2005-2015 on 327 enterprises employing panel model dynamic in nature. Trade credit usage and credit information sharing had a negative relationship as per study results. Conversely, Kusi et al. (2017) and Chavez, Jiang and Kushnir (2017) approved that credit channeled to enterprises from banks increases as credit information sharing lowers credit risk.

Asongu and Odhiambo (2018) carried out a study on information asymmetry, financialisation and financial access in South Africa. This study investigated whether information sharing networks had improved access to finances and reduction in information asymmetry. The study was done within 2004-2011 period utilising 53 countries in Africa. The study results was that significant and positive relationship existed among access to loans and credit information sharing. Teeranutranont (2017) carried out a study on the influence of credit information sharing on bank loans in 113 countries between 2005-2013 periods utilising panel model approach. The finding of the study shows that bank credit rises with increased credit information sharing. The result further revealed that credit information sharing minimises credit risk. The study suggested that CIS bridges the information gap between financiers and borrowers. Banks will increase loans granting, stability and minimal reservation of negative information with improved credit information sharing. In another study carried out by James et al. (2017) on credit accessibility and credit information sharing in Kenya. The study findings revealed that access to credit was positively and significantly influenced by credit information sharing. A study conducted by Gietzen (2016) on CIS and interest rates in banks found that CIS improves loans access at a cheaper rate since it eliminates the problems of adverse selection. The conceptual framework model illustrates the relationships amongst research variables based on established linkage from literature reviewed amid the study variables. 


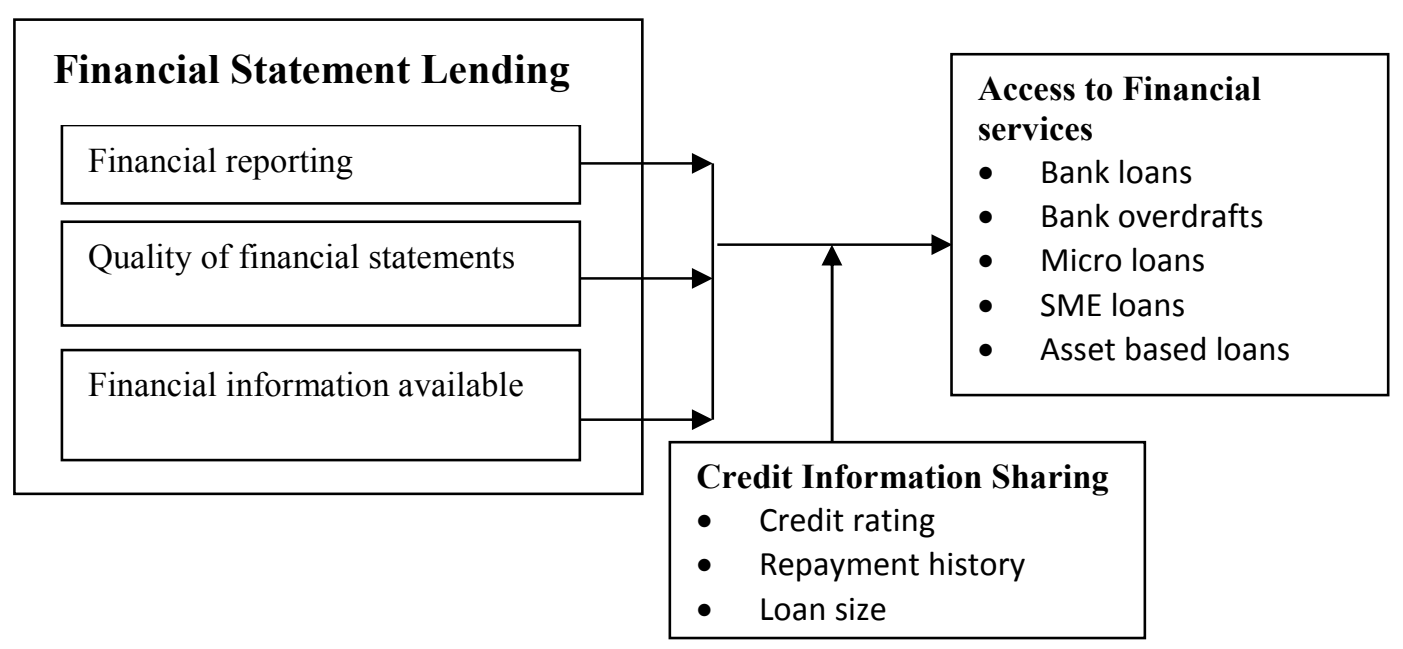

Figure 1: Conceptual Framework

\section{Research Methodology}

The study employed an explanatory research design. The descriptive information of a study is explained and accounted in the explanatory research. This design was effective to the study as it provides how the variables characteristics affect each other (Were \& Wambua, 2014) and the researcher did not manipulate the independent variables. Explanatory research enabled the researcher to establish causal relationships between financial statement lending and access to financial services. The target population for this study was 4,253 SMEs, comprising 4070 small enterprises and 183 medium enterprises licensed to operate in Lower Eastern Kenya. The unit of analysis was the SMEs while the unit of observation was owners of SMEs. Both stratified random sampling and cluster are combined to make the multistage sampling design which was adopted by the study. This sampling process is carried out in stages and involves a number of other sampling methods (Kothari, 2019).

The geographical location was used to determine the sample from the three county clusters. In the first stage of sampling, three clusters of SMEs were selected; Makueni County, Machakos County and Kitui County. The sample size of the study was selected from target population of 4253 SMEs that were licensed to operate in the Lower Eastern Kenya. In view of this, a representative sample was calculated from the accessible population at $95 \%$ confidence level using the formula as proposed by Yamane (1967). The sample of 366 was apportioned basing on percentage strength of numbers in every cluster as shown in Table 1.

Table 1: Sample Distribution

\begin{tabular}{|l|c|c|c|}
\hline Strata & $\begin{array}{c}\text { Population size } \\
(\mathrm{N})\end{array}$ & $\begin{array}{c}\text { Sample size } \\
(\mathrm{n})\end{array}$ & $\begin{array}{c}\text { Percentage } \\
(\mathrm{n} / \mathrm{N}) * 100\end{array}$ \\
\hline Small & 4070 & 350 & 95 \\
\hline Medium & 183 & 16 & 5 \\
\hline Total & 4253 & 366 & 100 \\
\hline
\end{tabular}

The questionnaire was used in collecting of the primary data which contains questions that were both open and close-ended. Data was analysed using both descriptive and inferential statistics. Inferential statistics that was included in this study involved the use of Heckman two step selection model to investigate the effect of financial statement lending on access to financial services by SMEs in Kenya. Thus, following the study of Ferri and Murro (2015) and Ferri, Murro, Peruzzi and Rotondi (2019) the model for access to financial services was illustrated as:

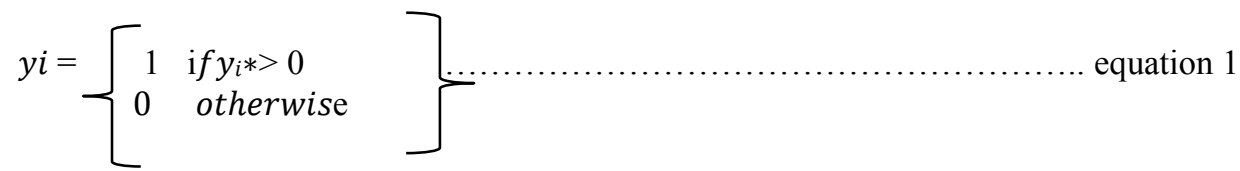

$y_{i}^{*}=\beta_{0+} \beta_{\mathrm{iXi}}+\varepsilon_{\mathrm{i}}$ .equation 2

Where:

$\mathrm{y}_{\mathrm{i}}=$ Access to financial services 
$\beta_{0}=$ Constant

$\beta \mathrm{i}=$ Vector of the regression coefficients

$\mathrm{X}_{\mathrm{i}}=$ Vector of Financial Statement lending.

$\varepsilon=$ Vector error term

\section{Results and Discussions}

The study administered a total of 366 questionnaires to selected respondents. The results in Table 4.1 show that 320 of the questionnaires were dully filled and returned which represented a response rate of $87.4 \%$. On the other hand, $46(12.6 \%)$ were not returned. The response rate of $87.4 \%$ was considered adequate for this study basing on the criteria provided by Babbie (2010) who suggested that for a descriptive study a response rate of above $50 \%$ should be accepted for analysis. The response rate was found to be adequate for analysis in line with observations made by Mugenda (2009) who concluded that a response rate of $50 \%$ is adequate for analysis and reporting, a rate of $60 \%$ is good while a response rate of $70 \%$ and above is excellent for analysis purposes. Grounded on these affirmations from prominent intellectuals, $87.4 \%$ response rate was excellent for the study. It is believed that a high response rate improves acceptance and reliability of research (Krishnan \& Pouloses, 2016).

\subsection{Descriptive Analysis}

The study sought to establish from the respondent whether their banks required financial statements before advancing credit to their enterprises. Table 2 presents the results of the outcome.

Table 2: Whether the bank always requests for financial statements before granting credit

\begin{tabular}{cccccc}
\hline & & Frequency & Percent & Valid Percent & Cumulative Percent \\
\hline \multirow{3}{*}{ Valid } & No & 39 & 12.2 & 12.2 & 12.2 \\
& Yes & 281 & 87.8 & 87.8 & 100.0 \\
& Total & 320 & 100.0 & 100.0 & \\
\hline
\end{tabular}

The results show that $87.8 \%$ of the respondent agreed. These findings implied that majority of the commercial banks carried out financial statement lending to SMEs. The results concurred with the findings of Aladejebi and Aladimeji (2019) affirming that absence of correct financial statement makes SMEs vulnerable in securing bank loans. The business information of the SMEs was the major factor that the bank required to give a loan (Saleh, Alkasasbeh \& Bader, 2017). Problems for SMEs to secure credit facility from financial institutions happens because of absence of appropriate financial statements (Aremu \& Adeyemi, 2011).

The study also sought the views of the respondents on the various components of financial statement lending on access to financial services by SMEs in Kenya. The views of the respondents are as shown in Table 3.

Table 3: Descriptive Results for Financial Statement Lending

\begin{tabular}{|c|c|c|c|c|c|c|c|}
\hline & $\begin{array}{c}\text { No } \\
\text { extent }\end{array}$ & $\begin{array}{c}\text { Low } \\
\text { extent }\end{array}$ & $\begin{array}{c}\text { Moderate } \\
\text { extent }\end{array}$ & $\begin{array}{l}\text { High } \\
\text { extent }\end{array}$ & $\begin{array}{l}\text { Very high } \\
\text { extent }\end{array}$ & Mean & Std Dev \\
\hline $\begin{array}{l}\text { Failure to provide financial } \\
\text { statements limits access to loans }\end{array}$ & $7.8 \%$ & $20.7 \%$ & $17.6 \%$ & $32.9 \%$ & $21.0 \%$ & 3.39 & 1.24 \\
\hline $\begin{array}{l}\text { Maintaining proper books of } \\
\text { accounts increases access to loans }\end{array}$ & $3.5 \%$ & $13.2 \%$ & $28.0 \%$ & $38.7 \%$ & $16.7 \%$ & 3.52 & 1.03 \\
\hline $\begin{array}{l}\text { Unsatisfactory disclosure of financial } \\
\text { information negatively affects access } \\
\text { to loans }\end{array}$ & $5.3 \%$ & $13.4 \%$ & $26.2 \%$ & $30.3 \%$ & $24.7 \%$ & 3.56 & 1.15 \\
\hline $\begin{array}{l}\text { Financial statements prepared } \\
\text { according to laid down accounting } \\
\text { standards increases access to credit }\end{array}$ & $5.0 \%$ & $15.0 \%$ & $21.9 \%$ & $29.5 \%$ & $28.5 \%$ & 3.61 & 1.19 \\
\hline $\begin{array}{l}\text { Unaudited financial statements } \\
\text { restrict access to loans }\end{array}$ & $7.2 \%$ & $10.1 \%$ & $26.7 \%$ & $26.1 \%$ & $29.9 \%$ & 3.61 & 1.21 \\
\hline $\begin{array}{l}\text { Availability of quality credible } \\
\text { financial information boosts business } \\
\text { access to loans }\end{array}$ & $4.4 \%$ & $12.3 \%$ & $20.8 \%$ & $31.5 \%$ & $30.9 \%$ & 3.72 & 1.16 \\
\hline $\begin{array}{l}\text { Inadequate evidence to assure future } \\
\text { cash flow for repayment negatively } \\
\text { affect access to loans }\end{array}$ & $6.9 \%$ & $14.7 \%$ & $19.7 \%$ & $30.0 \%$ & $28.8 \%$ & 3.59 & 1.24 \\
\hline $\begin{array}{l}\text { Insufficient confidence of financial } \\
\text { information provided restricts } \\
\text { granting of loans }\end{array}$ & $9.7 \%$ & $11.6 \%$ & $19.4 \%$ & $29.1 \%$ & $30.3 \%$ & 3.59 & 1.29 \\
\hline Firms insufficient profitability and & & & & & & & \\
\hline $\begin{array}{l}\text { liquidity limits access to loans } \\
\text { Overall mean }\end{array}$ & $8.8 \%$ & $11.2 \%$ & $16.9 \%$ & $29.1 \%$ & $34.1 \%$ & $\begin{array}{l}3.68 \\
3.59\end{array}$ & 1.29 \\
\hline
\end{tabular}


The results in table 3 presents the descriptive results of financial statement lending. To begin with, the study asked respondent whether failure to provide financial statements limits access to loans. The results show that $32.9 \%$ and $21.0 \%$ indicated high extent and very high extent respectively. On the other hand, $20.7 \%$ and $7.8 \%$ indicated low and no extent respectively. The finding implied that in some banks failure to provide financial statement limits access to loans but not in others. The respondents further indicated high extent as shown by the mean of 3.52 on the statement on whether maintaining proper books of accounts increases access to loans. The study findings are in agreement with Nemoto et al. (2018) accrediting that financial institutions need to assess credit risk and solvency of SMEs before extending credit as a result financial statements are always essential. Absence of organisational accounting expertise for decision making and non-existence of practical skills to make financial statements remain considerable problem to evolving of SMEs as is the failure to access loans (Karanja et al., 2014).

The study further sought to find out from the respondents whether unsatisfactory disclosure of financial information negatively affects access to loans. The results show that majority as indicated by mean of 3.56 indicate to high extent. Respondent further agreed that financial statements prepared according to laid down accounting standards increases access to credit. The results show that majority of the respondent agreed that unaudited financial statements restrict access to loans. This findings concurred with (UN, 2017) who affirmed that financial institutions finds enterprises financial statements valuable during loan requests but SMEs problems of access to financial services originate from insufficiency skills to adhere to IFRS in preparing financial statements.

The results in Table 3 further shown that respondent agreed on the statement on whether availability of quality credible financial information boosts business access to loans, inadequate evidence to assure future cash flow for repayment negatively affect access to loans, insufficient confidence of financial information provided restricts granting of loans and whether firms insufficient profitability and liquidity limits access to loans. The overall mean of 3.59 implied that majority of the respondents agreed on use of financial statement lending among the commercial banks in Kenya. The finding agreed with Boushnak et al. (2018) that credible financial statement positively and significantly influences securing of loan from banks. Similarly Ohachosim et al. (2017) indicated that quality of financial statements positively influences credit access by SMEs. Likewise, Ezeagba (2017) discovered that inadequate human resource, poor accounting system, failure to use banking system and lack of accounting records and books are the obstacles that SMEs experiences in preparation of financial reports and loan access.

\subsection{Model Fitting for the Effect of Financial Statement Lending on Access to Financial Services}

The study sought to find out whether financial statement lending has no statistical significant effect on access to financial services among SMEs in Kenya. The results are shown in Table 4.

Table 4: Heckman Selection Model-Two-Step Estimates

\begin{tabular}{|l|c|c|c|c|c|c|}
\hline Access financial services & Coef. & Std. Err. & $\mathrm{z}$ & $\mathrm{P}>|\mathrm{z}|$ & {$[95 \%$ Conf. } & Interval $]$ \\
\hline Financial Statement lending & 0.224912 & 0.066857 & 3.36 & 0.001 & 0.093875 & 0.355949 \\
\hline cons & 1.954402 & 0.259209 & 7.54 & 0.000 & 1.446361 & 2.462442 \\
\hline Wald chi2(3)=38.88 & & & & & & \\
\hline Prob $>$ chi2 = 0.0000 & & & & & & \\
\hline Number of obs & $=320$ & & & & & \\
\hline Censored obs & $=0$ & & & & & \\
\hline Uncensored obs & $=320$ & & & & & \\
\hline
\end{tabular}

The results in Table 4 show that the coefficient for financial statement lending was $\beta=0.224912$, $p=0.001<0.05$. The findings show that financial statement lending had a positive and significant effect on access to financial services among SMEs in Kenya. The results further show that increase in financial statement lending would result to increase in access to financial services among SMEs in Kenya by 0.224912 units. Based on these findings, the study rejected the null hypothesis that financial statement lending has no statistically significant effect on access to financial services among SMEs in Kenya. The finding agreed with Ezeagba (2017) who found that inadequate human resource, poor accounting system, failure to use banking system and lack of accounting records and books are the obstacles that SMEs experiences in preparation of financial reports and credit access. Minnis (2010) findings further indicated that audited financial statements are more informative and that this significantly influences lenders' decisions to grant credit.

The study finding also agreed with World Bank (2017) result that further revealed that low access to financing and increased credit costs results from unreliable financial statements and unsatisfactory disclosures of profits and credit risks. Banks too require current and periodic financial information; however, SMEs provide 
low quality information obscuring access to finance. Financial statements are utilised by banks in monitoring SMEs and fifty percent of loans granted are based on financial statements (Minnis \& Sutherland, 2016). However, in disagreement with the study results was Iswoyo et al. (2019) in a study on bank loan access and quality of SMEs financial statements. The study results showed that finanancial statements quality does not influence access to loans from banks since small and medium enterprises produces unreliable statements that are not verified hence do not reflect a true picture of the firm. In conclusion, the descriptive analysis showed that majority of the respondents agreed on use of financial statement lending among the commercial banks in Kenya. The findings of regression analysis further show that financial statement lending had a positive and significant effect on access to financial services among SMEs in Kenya. The results further show that increase in financial statement lending would result to increase in access to financial services among SMEs in Kenya.

4.3 Moderating Effect of CIS on the relationship between Financial Statement lending and access to financial services by small and medium enterprises in Kenya

Credit information sharing moderating effect was tested by a two-step procedure as specified by Whisman and Mc Clleland (2005). The first step including a model where CIS is treated as a predictor variable while in the second model CIS was treated as a moderating variable. In the first step the result for the moderation effect of credit information sharing being treated as a predictor variable is shown in Table 5.

Table 5: Step One: Test for Moderating Effect of CIS

\begin{tabular}{|c|c|c|c|c|c|c|}
\hline & & $\mathrm{B}$ & Std. Error & Beta & $\mathrm{t}$ & Sig. \\
\hline \multirow[t]{3}{*}{ Coefficients } & (Constant) & 1.839 & 0.28 & & 6.569 & 0.000 \\
\hline & Financial Statement lending & 0.309 & 0.088 & 0.228 & 3.503 & 0.001 \\
\hline & Credit Information Sharing & 0.096 & 0.076 & 0.082 & 1.259 & 0.209 \\
\hline \multirow[t]{4}{*}{ ANOVA } & & Sum of Squares & $\mathrm{df}$ & Mean Square & $\mathrm{F}$ & Sig. \\
\hline & Regression & 16.393 & 2 & 8.197 & 13.762 & $.000 \mathrm{~b}$ \\
\hline & Residual & 188.802 & 317 & 0.596 & & \\
\hline & Total & 205.196 & 319 & & & \\
\hline \multirow[t]{5}{*}{ Model Summary } & Model & 1 & & & & \\
\hline & $\mathrm{R}$ & .283 & & & & \\
\hline & R Square & 0.080 & & & & \\
\hline & Adjusted R Square & 0.074 & & & & \\
\hline & Std. Error of the Estimate & 0.77175 & & & & \\
\hline
\end{tabular}

The results in Table 5 show that financial statement lending had a coefficient of 0.309 with $\mathrm{p}=0.001<0.05$. The finding implied that financial statement lending significantly influence access to financial services by SMEs in Kenya. The coefficient of CIS was 0.096 with $p=0.209>0.05$. This implied that CIS had insignificant effect on access to financial services. Hence the study concluded that CIS can only act as a moderating variable of the relationship between financial statement lending and access to financial services among the SMEs in Kenya. In the second step the results for the moderation effect of credit information sharing being treated as a moderating variable are shown in Table 6.

Table 6: Step Two: Test for Moderating Effect of CIS

\begin{tabular}{|c|c|c|c|c|c|c|}
\hline Model & & $\mathrm{B}$ & Std. Error & Beta & $\mathrm{t}$ & Sig. \\
\hline \multirow[t]{4}{*}{ Coefficients } & (Constant) & 2.776 & 0.99 & & 2.803 & 0.005 \\
\hline & Financial Statement lending & 0.028 & 0.298 & 0.021 & 0.094 & 0.925 \\
\hline & Credit Information Sharing Mean & -0.182 & 0.291 & -0.156 & -0.624 & 0.533 \\
\hline & Financial Statement lending *CIS & 0.081 & 0.083 & 0.397 & 0.986 & 0.325 \\
\hline \multirow[t]{4}{*}{ ANOVA } & & $\begin{array}{l}\text { Sum of } \\
\text { Squares }\end{array}$ & $\mathrm{df}$ & $\begin{array}{c}\text { Mean } \\
\text { Square }\end{array}$ & $\mathrm{F}$ & Sig. \\
\hline & Regression & 16.973 & 3 & 5.658 & 9.498 & $.000 \mathrm{~b}$ \\
\hline & Residual & 188.223 & 316 & 0.596 & & \\
\hline & Total & 205.196 & 319 & & & \\
\hline \multicolumn{7}{|l|}{ Model } \\
\hline \multirow[t]{4}{*}{ Summary } & $\mathrm{R}$ & $.288 \mathrm{a}$ & & & & \\
\hline & R Square & 0.083 & & & & \\
\hline & Adjusted R Square & 0.074 & & & & \\
\hline & Std. Error of the Estimate & 0.77178 & & & & \\
\hline
\end{tabular}


variable financial statement lending ${ }^{*} \mathrm{CIS}(\beta=0.081, \mathrm{p}=0.325>0.05)$ were all insignificant. The results implied that CIS had insignificant moderating effect on the relationship between financial statement lending and access to financial services among the SMEs in Kenya. This findings are in line with Ahmad et al. (2018) that credit information sharing has a negative relationship with credit access. Similarly Bos, de Haas and Millone (2016) discovered that SMEs increased loan rejection in Herzegovina and Bosnia arose from tightening of credit terms by banks as a result of CIS. This finding contradicts those of Son et al. (2020) and Asongu and Odhiambo (2018) results that showed credit information sharing had a significant as well as a positive influences on financial intermediation activities.

\section{Conclusion and Recommendation \\ 5.1 Conclusion}

The study concluded that financial statements play a critical role in ensuring small and medium enterprises access financial services. Lenders can assess and determine the financial position of the business by analysing their cashflow in order to be able to advance the credit that the business is able to pay based on their financial statement. Majority of the SMEs in Kenya lack audited financial statement which block them out from accessing financial services from formal lending institutions. The study further concluded that lending institution in Kenya have adopted the CIS to be able to identify defaulters. This CIS systems such as CRB has helped lending institution to identify risk borrowers but at the same time has further increased credit inaccessibility by SMEs in Kenya. The study finally concluded that financial literacy training plays a significant role in increasing access to financial services by small and medium size enterprises in Kenya.

\subsection{Recommendations}

The study recommends that SMEs should start and maintain accurate financial statements which lending institution can utilise to determine their financial power to repay credit if granted. The study also recommends that policy maker should relook at the CIS systems to ensure they do not further make it worse for SMEs owned by financially marginalized groups. Similarly, CIS should be approved with caution to address the problem of credit inaccessibility. The study further recommends that board of director of lending institutions should come up with policies to ensure that financial training short courses are offered to SMEs owners and managers before advancing credit to them.

\subsection{Future Research}

The study focused on financial statement lending and how it affect access to financial services by small and medium enterprises in Kenya. There exist gaps on other financing practices such as lending based on business viable models therefore further studies should focus on other financing practices besides financial statement lending and how they affect access to financial services by small and medium enterprises.

\section{References}

Aga, G. A. \& Reilly, B. (2011). Access to credit and informality among micro and small enterprises in Ethiopia. International Review of Applied Economics, 25(3), 313-329.

Ahmad, N., Nazir, S. M. \& Nafees, B. (2018). Impact of financial development and credit information sharing on the use of trade credit: Empirical evidence from Pakistan. Cogent Economics \& Finance, 6 (1), 1-17.

Aladejebi, O. \& Aladimeji, J. A. (2019). The Impact of Record Keeping on the Performance of Selected Small and Medium Enterprises in Lagos Metropolis. Journal of Small Business and Entrepreneurship Development, 7, (1), 28-40.

Andabai, P. W. \& Eze, G. P. (2018). Bank Credit and Manufacturing Sector Growth in Nigeria (1990-2017): A Causality Investigation. International Journal of Economics, Commerce and Management, 6 (3), 326-336.

Angilella, S. \& Mazzù, S. (2017). A credit risk model with an automatic override for innovative small and medium-sized enterprises. Journal of the Operational Research Society, 70 (10), 1-20.

Aremu, M. A. \& Adeyemi, S. L (2011). Small and medium scale enterprises as a survival strategy for employment generation in Nigeria. Journal of Sustainable Development, 4 (1), 200-206.

Asong, S. A. \& Odhiambo, M. N. (2018). Information Asymmetry, Financialisation and Finance Access. International Finance, 21(3), 297-315.

Babbie, E. (2010). The Practice of Social Research. Wadsworth publishers, USA 12th edition.

Balakrishnan, K. \& Ertan, A. (2021). Credit information sharing and loan loss recognition. Accounting Review. LBS Research Online American Accounting Association. http://lbsresearch.london.edu/id/eprint/1539/

Berg, G., Fuchs, M., Ramrattan, R., Totolo, E. \& Central Bank of Kenya. (2015). Fin Access Business - Supply: Bank Financing of SMEs in Kenya, Financial Sector Deepening Trust Kenya, Nairobi, Kenya.

Bos, J. W. B., De Haas, R. \& Millone, M. (2016). Show Me Yours and I'll Show You Mine: Sharing Borrower Information in a Competitive Credit Market. BAFFI CAREFIN Centre Research Paper No. 2015-8. 
Boushnak, E., Rageb, M.A., Ragab, A. A. \& Sakr, A.M. (2018). Factors Influencing Credit Decision for Lending SMEs: A Case Study on National Bank of Egypt. Open Access Library Journal, 5, 1-17.

Brown, M., Ongena, S., Popov, A. \& Yesin, P. (2011). Who Needs Credit and Who Gets Credit in Eastern Europe. Economic Policy, 26, 93-130.

CBK (2017). The Kenya Bankers Association Sixth Annual Banking Research Conference, Nairobi, Kenya.

CBK (2018). The Impact of Interest Rate Capping on the Kenyan Economy: Highlights. Central Bank of Kenya.

Chavez, E. (2017). Credit Information and Firms' Access to Finance: Evidence from a New Credit-Constrained Status Measure. Doing Business unit, World Bank Group.

Chavez, E., Jiang, N. C. \& Kushnir, K. (2017). Getting Credit: Credit Information. Doing Business 2017.

Chitom, J. R. \& Muogbo, U. S. (2018). The Role of Commercial Banks in Financing SMEs in Nigeria: A study of selected banks and firms in Anambra State, Nigeria. European Journal of Economic and Financial Research, 3 (1), 1-20.

Chowdhury, M. \& Alam, Z. (2017). Factors affecting access to finance of small and medium enterprises of Bangladesh, the USV Annals of Economics and Public Administration, 17, (2), 26-50.

Ezeagba, E. C. (2017). Financial Reporting in Small and Medium Enterprises in Nigeria. Challenges and Options. International Journal of Academic Research in Accounting, Finance and Management Sciences, 7 (1), 1-10.

Ferri, G. \& Murro, P. (2015). Do firm-bank 'odd couples' exacerbate credit rationing? Journal of Financial Intermediation, 24(2), 231-251.

Ferri, G., Murro, P., Peruzzi, V. \& Rotondi, Z. (2019). Bank lending technologies and credit availability in Europe: What can we learn from the crisis? Journal of International Money \& Finance, 9,128-148.

Fosu, S., Danso, A. Agyei-Boapeah, H. and Ntim, C. G. \& Adegbite, E. (2019). Credit Information Sharing and Loan Default in Developing Countries: The Moderating Effect of Banking Market Concentration and National Governance Quality. Review of Quantitative Finance and Accounting, 55, 55-103.

FSD Kenya (2017). Creating value through financial inclusion. Annual report 2016.

Fuseini, G. Nuakoh, Amponsah (2015). Small and Medium-Sized Enterprises (SMEs') Access to Credit in Ghana: Determinants and Challenge. Unpublished MPhil thesis, University of Ghana, Legon.

Gietzen, T. (2016). The impact of credit information sharing on interest rates. Working Papers on Finance No. 2016/12. Swiss Institute of Banking and Finance. $\quad$ University of St. Gallen.

Gurley, J. G., \& Shaw, E. S. (1967). Financial structure and economic development. Economic development and cultural change, 15(3), 257-268.

Hoque, M. Z, Sultana, N. \& Thalil, T. (2016). Credit rationing's determinants of Small and Medium Enterprises in Chittagong, Bangladesh Journal of Global Entrepreneurship Research, 6 (1), 1-23.

Iswoyo, A., Ermawati, Y. \& Nugroho, A. (2019). SMEs Financial Report: Between Quality and Access to Bank Credit. KnE Soc. Science, 3 (11), 651.

James, R., Iraki, X. \& Korir, J. (2017). Credit Information Sharing and Credit Availability in Kenya. European Journal of Business and Management, 9 (34), 36-44.

Jin, Y. \& Zhang, S. (2019). Credit Rationing in Small and Micro Enterprises: A Theoretical Analysis. Sustainability MDPI Journal, (11), 1-15.

Kaberia, K. S. \& Muathe, S. M. A. (2021). Effect of Covid-19 Pandemic on Performance of Women Owned Micro, Small and Medium Enterprises in Kenya. International Journal of Social Science Studies, 9 (1), 7-21.

Karanja, J. G., Mwangi, A. K. \& Nyakarimi, S. N. (2014). Analysis of Factors Inflencing Access to Credit Services by Women Entrepreneurs in Kenya. Research Journal of Finance And Accounting, 5(11), 14-21.

KBA (2012). Collateral Lending: Are there Alternatives for the Kenyan Banking Industry? KBA Centre for Research on Financial Markets and Policy Working Paper Series.

Kenya Bankers Association (2017). Impact of interest rate capping on Kenyan economy. Nairobi: Government Press.

Kiplimo, J. C., Ngenoh, E., Koech, W. \& Bett, J. K. (2015). Determinants of Access to Credit Financial Services by Smallholder Farmers in Kenya. Journal of Development and Agricultural Economics, 7(9), 303-313.

KNBS (2016). Micro, Small and Medium Establishment (MSME) Survey.

Kothari, C. R. (2019). Research Methodology: Methods and Techniques. 4th ed, New Age International Publishers, New Delhi.

Krishnan, T. N. \& Pouloses, S. (2016). Response rate in industrial surveys conducted in India: Trends and implications. IIMB Management Review, 28 (2), 88-97.

Kusi, B.A., Agbloyor, E. K., Ansah-Adu, K. \& Dako, A.G. (2017). Bank Credit Risk and Credit Information Sharing in Africa. Research in International Business and Finance, 42, 1123-1136.

Kwaning, C. O., Nyantakyi, K. \& Kyereh, B. (2015). The challenges behind SMEs access to debts financing in the Ghanaian financial market. International, Journal of Small Business and Entrepreneurship Research, $3(2), 16-30$.

Martinez, P., Maria S. \& Singh, S. (2014). The Impact of Credit Information Sharing Reforms on Firm 
Financing? Policy Research Working Paper; No. 7013. World Bank Group, Washington, DC.

Mashkour, S. C. (2020). Analysis of financial statements. (2nd ed.). Muthanna University, Research Gate.

Mazeri, A. \& Saadouni M. (2019). The Impact of Information Asymmetry on the Bank Financing of SMEs in Algeria: An Econometric Study. International Journal of Inspiration \& Resilience Economy, 3(1), 17-23.

Mbatha, N. \& Ngibe, M. (2017). Factors Affecting Financial Stability of Small and Medium Enterprises: A case Study of Emerging Markts. Risk governance \& control: financial markets \& institutions, 7, (1), 7-17.

Minnis, C. M. (2010). The Value of Verification in Debt Financing: Evidence from Private U.S. Firms, PhD Dissertation, The University of Michigan.

Minnis, M. \& Sutherland, A. (2016). Financial Statements as Monitoring Mechanisms: Evidence from Small Commercial Loans. Journal of Accounting Research, 55 (1), 197-233.

Mugenda, O. M. (2009). Higher education in Kenya: Challenges and opportunities. In A Paper Presented at AHEC Meeting (Vol. 30).

Mungiria, B. J. \& Ondabu, T. I. (2019). Role of Credit Reference Bureau on Financial Intermediation: Evidence from the Commercial Banks in Kenya. International Journal of Finance and Accounting, 8 (3), 73-79.

Ndede, W. S., Wawire, N. H. W. \& Mbewa M. O. (2015). Determinants of acquisition of financial services by micro and small enterprises in Langata Sub-county of Nairobi County, PhD Thesis, Kenyatta University.

Nega, F. \& Hussein, G. (2016). Small and Medium Enterprise Access to Finance in Ethiopia: Synthesis of Demand and Supply. The Horn Economic and Social Policy Institute (HESPI) Working Paper 01/16.

Nemoto, N., Yoshino, N., Okubo, Y., Inaba, D. \& Yanagisawa, K. (2018). Credit Risk Reduction Effect on Small and Medium-Sized Enterprise Finance through the Use of Bank Account Information. ADBI Working Paper 857. Tokyo: Asian Development Bank Institute.

OECD (2018). Enhancing SME access to diversified financing instruments. SME Ministerial Conference, 22-23 February 2018 Mexico City.

Ohachosim, C. I., Onwuchekwa, F. C. \& Ifeanyi, T. T. (2017). Evaluating the extent accounting information can be used to ameliorate the financial challenges of SMEs in Nigeria. Review of Public Administration and Management, 1 (2), 248-276.

Otieno, S., Nyagol, M. \& Onditi, A. (2016). Relationship between Credit risk management and financial performance: empirical evidence from microfinance banks in Kenya. Research Journal of Finance and Accounting, 7, (6), 115-142.

Pandula, G. (2013). Determinants of access to bank finance for small and medium-sized enterprises: The case of Sri Lanka. Corporate Ownership and Control, 10 (3), 314-321.

Saleh, A. M., Alkasasbeh, M. A. \& Bader, A.A. (2017). The Role of Financial Analysis Tools in Granting Loans. A Field study on Banks Operating within Aqaba Special Economic Zone. International Journal of Academic Research in Accounting, Finance and Management Sciences, 7 (1), 75-85.

Sari, A.I., Rahmatika, N. D., Fajri, A. \& Muttaqin, I. (2020). Quality of Financial Statements and Its Effects on Received Credits for Small Medium Enterprise, Indonesia. European Journal of Business and Management Research, 5 (1), 1-6.

Son, H.T., Khanh, G. H. \& Liem, T. N. (2020). Credit information sharing, corruption and financial development: International evidence. Cogent Business and Management, 7 (1), 1-15.

Teeranutranont, C. (2017). The Impact of Credit Information Sharing in Banking Sectors, Doctoral Thesis, Durham University.

UN, (2017). Small and Medium Enterprise Financing. Economic and Social Development Centre for the United Nations in Asia and the Pacific, working paper.

Were, M. \& Wambua, J. (2014). What factors drive interest rate of commercial banks? Empirical evidence from Kenya. Review of Development Finance, 4 (2), 73-82.

Whisman, M. A. \& Mc Clelland, G. H. (2005). Designing, Testing, and Interpreting Interactions and Moderator Effects in Family Research. Journal of Family Psychology, 19 (1), 111-120.

Word Bank (2018). Improving Access to Finance for SMEs through Credit Reporting, Secured Lending and Insolvency Practices.

Word Bank (2017). Improving Access to Finance for SMEs through Credit Reporting, Secured Lending and Insolvency Practices.

Yamane, T. (1967). Statistics: An Introductory Analysis, $2^{\text {nd }}$ Edition, New York: Harper and Row. 